\title{
Calciphylaxis of the breast: a rare metabolic complication of kidney disease
}

\author{
Abhilash Koratala, Abutaleb A Ejaz, Rajesh Mohandas
}

Department of Nephrology, University of Florida College of Medicine, Gainesville, Florida, USA

\section{Correspondence to} Dr Abhilash Koratala, akoratsla@ufl.edu

Accepted 26 July 2016

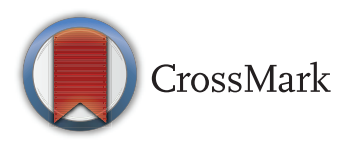

To cite: Koratala $A$, Ejaz AA, Mohandas R. BMJ Case Rep Published online: [please include Day Month Year] doi:10.1136/bcr-2016216665

\section{DESCRIPTION}

Calcific uraemic arteriolopathy (CUA) or calciphylaxis affects $1-4 \%$ of the population with end stage renal disease (ESRD) and associated with high mortality. Most lesions (90\%) occur on the lower extremities ${ }^{1}$ followed by the lower abdomen. We report a severe case of CUA in an uncommon location-the breasts.

A 54-year-old Caucasian woman with end stage kidney disease secondary to diabetic nephropathy, on maintenance haemodialysis for a year, was admitted with painful, open wound of the right breast. The initial lesion was a tender nodule which progressed to open wound with surrounding redness and intense pain over a 3-month period. The patient also noticed similar tender nodule in the left breast a few months later. Physical examination revealed eschar lesion over the medial superior right breast with a $1 \mathrm{~cm}$ deep area of tunnelling, firmness and induration underlying this area with surrounding erythema. (A) The left breast revealed erythema and a subcutaneous nodule on the medial aspect with no open lesions. (B) Laboratory data were significant for haemoglobin $10 \mathrm{~g} / \mathrm{dL}$, erythrocyte sedimentation rate $96 \mathrm{~mm} /$ hour, serum creatin-
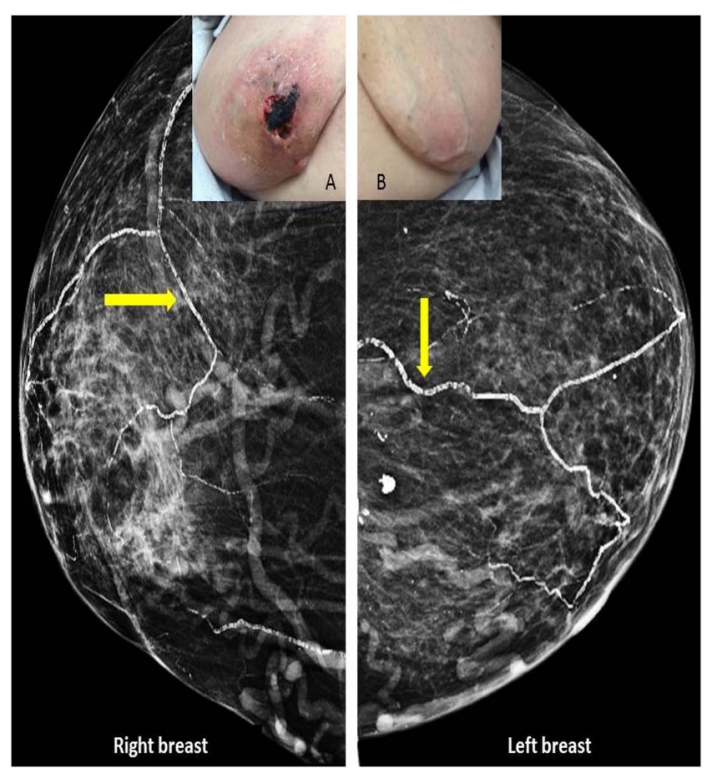

Figure 1 Mammogram showing extensive vascular calcifications (arrows point to calcified arteries) and scattered microcalcifications in breasts. Clinical examination findings of the breasts showing in the inset ((A) -right breast, (B)—left breast). ine of $5.6 \mathrm{mg} / \mathrm{dL}$, phosphate $6.2 \mathrm{mg} / \mathrm{dL}$, parathyroid hormone $340 \mathrm{pg} / \mathrm{mL}$, albumin $2.8 \mathrm{~g} / \mathrm{dL}$ and alkaline phosphatase of $186 \mathrm{U} / \mathrm{L}$. Mammogram demonstrated extensive vascular calcifications and scattered microcalcifications in breasts (figure 1). Punch biopsy of the lesion showed skin and subcutaneous tissue with mild acute and chronic inflammation, fibrosis and focal necrosis. Focal calcium deposition was seen within a small blood vessel. Findings were compatible with the diagnosis of CUA. Therapy, including sodium thiosulfate with dialysis, was initiated and warfarin was discontinued. Lesions showed improvement at 1 month follow-up visit.

\section{Learning points}

- High index of suspicion required for diagnosis of calcific uraemic arteriolopathy (CUA) in atypical locations in dialysis patients.

- High calcium-phosphate product, elevated parathyroid hormone, hypoalbuminaemia, diabetes, obesity, warfarin use, female sex and protein $\mathrm{C}$ or $\mathrm{S}$ deficiency are among the risk factors for CUA. ${ }^{2}$

- Prompt and aggressive treatments with sodium thiosulfate, ${ }^{3}$ adequate dialysis, nutrition support and supportive care are important to reduce the morbidity and mortality of this once uniformly fatal disease.

Contributors AK prepared the manuscript for submission and acquired the images. AAE reviewed and revised the manuscript, and RM reviewed the manuscript and approved for submission.

Competing interests None declared.

Patient consent Obtained.

Provenance and peer review Not commissioned; externally peer reviewed.

\section{REFERENCES}

1 Saifan C, Saad M, El-Charabaty E, et al. Warfarin-induced calciphylaxis: a case report and review of literature. Int I Gen Med 2013;6:665-9.

2 Floege J, Kubo Y, Floege A, et al. The effect of cinacalcet on calcific uremic arteriolopathy events in patients receiving hemodialysis: the EVOLVE trial. Clin J Am Soc Nephrol 2015;10:800-7.

3 Nigwekar SU, Brunelli SM, Meade D, et al. Sodium thiosulfate therapy for calcific uremic arteriolopathy. Clin J Am Soc Nephrol 2013;8:1162. 
Copyright 2016 BMJ Publishing Group. All rights reserved. For permission to reuse any of this content visit http://group.bmj.com/group/rights-licensing/permissions.

BMJ Case Report Fellows may re-use this article for personal use and teaching without any further permission.

Become a Fellow of BMJ Case Reports today and you can:

- Submit as many cases as you like

- Enjoy fast sympathetic peer review and rapid publication of accepted articles

- Access all the published articles

- Re-use any of the published material for personal use and teaching without further permission

For information on Institutional Fellowships contact consortiasales@bmjgroup.com

Visit casereports.bmj.com for more articles like this and to become a Fellow 